\title{
POSICIONAMENTO ESTRATÉGICO E ESTABILIDADE ESTRATÉGICA: QUAL A IMPORTÂNCIA PARA O DESEMPENHO?
}

\section{STRATEGIC POSITIONING AND STRATEGIC STABILITY: DOES IT MATTER TO PERFORMANCE?}

\section{POSICIONAMIENTO ESTRATÉGICO Y ESTABILIDAD ESTRATÉGICA: ¿LE IMPORTA A RENDIMIENTO?}

\author{
Jorge Ferreira da Silva \\ Doutor em Engenharia de Produção pela Pontifícia Universidade Católica do Rio de Janeiro - \\ PUC/RJ \\ Professor e Coordenador de Pós-Graduação em Administração de Empresas da Pontifícia \\ Universidade Católica do Rio de Janeiro - PUC/RJ \\ E-mail: jorge1319@gmail.com (Brasil)
}

\section{Walter Pereira Formosinho Filho}

Mestre em Administração pela Pontifícia Universidade Católica do Rio de Janeiro - PUC/RJ

E-mail: exfahr@gmail.com (Brasil)

\section{Jorge Manoel Teixeira Carneiro}

Doutor em Administração pela Universidade Federal do Rio de Janeiro - UFRJ

Professor da Pontifícia Universidade Católica do Rio de Janeiro - PUC/RJ

E-mail: jtcarneiro@gmail.com (Brasil)

\section{Jorge Brantes Ferreira}

Doutor em Administração de Empresas - Marketing pelo Instituto Coppead de Administração pela Universidade Federal do Rio de Janeiro - UFRJ

Professor da Pontifícia Universidade Católica do Rio de Janeiro - PUC/RJ

E-mail: jorgebf@gmail.com (Brasil) 
Strategic Positioning and Strategic Stability: Does it Matter to Performance?

\title{
POSICIONAMENTO ESTRATÉGICO E ESTABILIDADE ESTRATÉGICA: QUAL A IMPORTÂNCIA PARA O DESEMPENHO?
}

\section{RESUMO}

Este estudo investiga se as empresas petrolíferas multinacionais de petróleo (MNCs) adotaram posicionamento estratégico distinto e se o posicionamento estratégico e desempenho da empresa estão relacionados. A análise de cluster de 50 empresas identificaram 10 tipos estratégicos. Apesar de não haver diferenças estatisticamente significativas foram encontradas no desempenho futuro esperado em uma base anual, houve diferenças estatisticamente significativas no desempenho passado entre os tipos estratégicos em cinco dos últimos oito anos (2000 - 2007) do estudo. Além disso, a média para todo o período , alguns tipos estratégicos apresentaram desempenho futuro esperado superior e alguns alcançado o desempenho passado superior. Além disso , a estabilidade em posição estratégica - ou seja, mantendo a mesma posição estratégica para um longo período de tempo - foi também associada a um melhor desempenho .

Palavras-chave: Posicionamento Estratégico; Companhias Petrolíferas Multinacionais; Desempenho da Empresa.

\section{STRATEGIC POSITIONING AND STRATEGIC STABILITY: DOES IT MATTER TO PERFORMANCE?}

\begin{abstract}
This study investigates whether oil multinational oil companies (MNCs) have adopted distinct strategic positioning and whether strategic positioning and firm performance are related. Cluster analysis of 50 firms identified 10 strategic types. Although no statistically significant differences were found in expected future performance on an annual basis, there were statistically significant differences in past performance between strategic types in five out of the eight years $(2000-2007)$ of the study. Also, averaged over the entire period, some strategic types presented higher expected future performance and some achieved higher past performance. Moreover, stability in strategic positioning - that is, keeping the same strategic positioning for a longer period of time - was also associated with better performance.
\end{abstract}

Keywords: Strategic Positioning; Multinational Oil Companies; Firm Performance. 


\section{POSICIONAMIENTO ESTRATÉGICO Y ESTABILIDAD ESTRATÉGICA: ¿LE IMPORTA A RENDIMIENTO?}

\section{RESUMEN}

Este estudio investiga si las compañías petroleras multinacionales petroleras (EMN) han adoptado un posicionamiento estratégico distinto y si el posicionamiento estratégico y el desempeño de la empresa están relacionados . El análisis de conglomerados de 50 empresas se identificaron 10 tipos estratégicos. Aunque no se encontraron diferencias estadísticamente significativas en el rendimiento futuro esperado sobre una base anual, no hubo diferencias estadísticamente significativas en los resultados anteriores entre los tipos estratégicos en cinco de los ocho años (2000 - 2007) del estudio. Además, en promedio durante todo el período, algunos tipos estratégicos presentados rendimiento futuro esperado más alto y algunos logrado rentabilidades pasadas superior. Por otra parte, la estabilidad en el posicionamiento estratégico - es decir, manteniendo el mismo posicionamiento estratégico para un período más largo de tiempo - también se asoció con un mejor rendimiento .

Palabras-clave: Posicionamiento Estratégico; Las Compañías Petroleras Transnacionales; Desempeño de la Empresa . 


\section{INTRODUCTION}

The oil industry plays an important role in the economy, since firms and consumers depend heavily on their products, particularly fuels and petrochemicals. Oil companies have experienced several transformations, either imposed by governmental policies - for instance, privatization and regulation - or forced by changes in the nature of competition, which have led to partnerships, mergers, acquisitions, and internationalization. In response to changes in the competitive environment, companies need to make decisions about their strategic positioning in order to preserve or improve their performance levels, as capital market investors put ever more pressure on them.

The purpose of this study is two-fold: to investigate whether multinationals in the oil industry (oil MNCs) differ in their strategic positioning; and to verify whether there seems to be some association between strategic positioning and firm performance in the oil industry.

In order to answer this question, this paper has been organized in five parts. After this introduction, a review of the literature is presented to cover concepts of generic competitive strategies and of organizational performance. Then, data collection and treatment methods are laid out. Findings are subsequently shown and discussed. Finally, conclusions and suggestions for future studies close the paper.

\section{THEORETICAL BACKGROUND}

Literature suggests that several factors seem to bear influence on firms' performance. In fact there are three major areas of influence: the external environment, each company's idiosyncratic characteristics, and the strategic positioning they adopt (McGahan and Porter, 1997, 2002; Roquebert, Phillips and Westfall, 1996; Rumelt, 1991).

In this paper, we are interested in assessing, particularly, the impact of strategy upon performance.

\subsection{TYPOLOGIES OF GENERIC COMPETITIVE STRATEGIES}

The position of a company's offer - in terms of the attributes that offer presents to customers and their comparison with what is offered by competitors and substitutes - is, in most situations, a multidimensional construct. 
Strategic positioning may be described as the emphasis that a firm employs in each competitive method (for instance, branding, quality, services, etc.). However, as the number of relevant attributes increases, it may become cumbersome to describe the strategy.

On the other hand, typologies, or classification schemes, capture the essence of the various relevant characteristics, simplifying the understanding and visualization of complex combinations. According to Hambrick (1983), the use of typologies reduces the vast array of combinations that a researcher would have to consider, given that the types (or categories) of a typology would represent general characters (archetypes or gestalts), which would define a holistic package of attributes. These archetypes are wholes that represent the simultaneous and conjoint interactions taking place (Venkatraman and Prescott, 1990), thus better reflecting the complex nature of the phenomenon. As Namiki (1994) has put it, the use of profiles makes it possible to compare the conjoint impact of distinct patterns of combination of variables. Once the corresponding archetype is identified, several other characteristics could be inferred (Miller, 1981). The choice of which dimensions would better represent a given construct may be based on theory and on conceptual reflections; or, alternatively, the dimensions and categories (types) of the model may be derived empirically, from the classification of a set of observations - in this case, one would have a taxonomy.

Two often referenced typologies of generic competitive strategies are Porter's (1985) and Mintzberg's (1988).

Porter's (1985) typology is based on two dimensions:

- competitive advantage over competitors (low cost or differentiation); and

- breadth of target-market (broad vs. narrow coverage of market segments).

Mintzberg's (1988) typology implicitly ignores costs and focuses on the distinction between five types of differentiation - quality, project, support, image, and low price - and an additional strategic positioning based on imitating competitors: non-differentiation.

However, the implicit supposition in Porter's (1985) typology that simultaneous search for differentiation and low cost would not be possible, in theory, except for (supposedly rare) particular circumstances, was criticized by several other researchers who found empirical evidence (e.g., Miller and Dess, 1993) and conceptual justifications (e.g., Dess and Davis, 1984; Hill, 1988; and Wright, 1987) to argue that emphasis on both competitive dimensions could be simultaneously achieved with success. 
Strategic Positioning and Strategic Stability: Does it Matter to Performance?

Miller and Dess (1993) proposed a typology, according to which the concepts of cost, differentiation, and scope of target market would comprise dimensions of strategic positioning. Instead of assuming discrete positions, companies would occupy positions in a continuum along the three dimensions: level of differentiation, level of cost, and breadth of market scope. Considering, in order to simplify the analysis, that each of these dimensions could assume values at three levels (e.g., high, middle, and low), there would then be $3^{3}=27$ possible combinations. Nevertheless, only some of these combinations would be of practical interest (e.g., the combination between high cost and low differentiation has obviously no appeal). On behalf of parsimony, Miller and Dess (1993) limited their model to seven more plausible combinations: differentiation + low cost + narrow scope; differentiation + low cost + broad scope; differentiation + narrow scope; differentiation + broad scope; low cost + narrow scope; low cost + broad scope; and stuck-in-the-middle (characterized by an intermediary positioning in each of the three dimensions of cost, differentiation, and scope of target-market).

Chrisman, Hofer and Boulton (1988) suggested a typology that considers, not only an offer's positioning (e.g., low cost or differentiation) and market scope (as in Miller and Dess, 1993), but also allows for the possibility of using distinct strategic positioning across the several market segments a firm servers (which they called "presence of segment differentiation"). Their classification model is based on the following three dimensions (and respective levels on each dimension):

1. breadth of market scope

- broad

- narrow

2. type of competitive weapon accounting for all or most of the firm's revenues

- low cost / low price

- balanced use of low cost / low price and differentiation (utility)

- differentiation

- few or no competitive weapons (i.e., neither lower cost nor differentiation versus competitors' offers)

3. presence of segment differentiation

- yes (i.e., different types of competitive weapons used in different segments) 
- no (i.e., same type of competitive weapons used in each of the segments served by the company)

The word "utility" was used by Chrisman et al. (1988) to designate a strategic type that would simultaneously employ low cost and differentiation methods in their main product/market segment(s). It should be noted that the use of low cost in a segment and differentiation in another shows diversity per segment (that is, different positioning in different segments) and not necessarily utility (which would indicate that both competitive methods would be used at the same time in the same segment or segments). A company may also use both methods simultaneously in a given segment while using only one of them in another segment - which characterizes diversity per segment. So, if the segment (or segments) where both methods are used simultaneously is responsible for most corporate revenues, this strategy would be classified as segmented utility or segmented utility focus, depending on an either broad or narrow scope, respectively.

When adopting differentiation as a competitive method, a company would try to incorporate new attributes or to increase the level of present attributes in relation to competitors in order to attract customer preference. Concerning cost leadership, Chrisman et al. (1988) considered that a low cost position per se would not generate competitive advantage unless it was translated into low price to customers. Chrisman et al (1988) considered that eliminating or reducing benefits less appreciated by customers may develop cost advantage in products that, despite reduced level of benefits, would still be differentiated if the product continued to offer the attributes considered relevant for the market it is set to serve. The utility strategy could be referred to as a balance between cost and benefits, in an attempt to reconcile two competitive advantages and create greater economic value in relation to competitors.

The strategy of no competitive weapon, presented in Chrisman et al.'s (1988) typology, would be related to those companies that do not use any particular competitive weapon and are, at most, content with meeting excess demand. These companies have no type of competitive advantage, except maybe for being in the right place at the right time.

Considering the combinations of two levels of scope and two levels of diversity in positioning per segment with the four competitive methods, Chrisman et al.'s (1988) typology would be composed of a set of $2 \times 2 \times 4=16$ strategic types. However, a combination of positioning diversity per segment with no competitive weapon is internally inconsistent, since without choosing any competitive method a company cannot present different competitive methods in different segments be it in the case of broad scope or in the case of narrow scope. After excluding these two 
Strategic Positioning and Strategic Stability: Does it Matter to Performance?

strategic types, Chrisman et al.'s (1988) typology comprises a total of 14 strategic types (see Table 1, which presents the association between every strategic type of Chrisman et al. (1988) and the respective empirically derived cluster, as detailed further ahead).

Table 1 - Association between the strategic types by Chrisman et al. (1988) and clusters derived in the study

\begin{tabular}{|c|c|c|c|c|c|c|c|}
\hline & & & & \multicolumn{4}{|c|}{$\begin{array}{l}\text { TYPES OF COMPETITIVW METHOD RESPONSIBLE } \\
\text { FOR MOST CORPORATE REVENUES }\end{array}$} \\
\hline & & & & COST/PRICE & UTILITY & DIFFERENTIATION & NONE \\
\hline \multirow{4}{*}{ 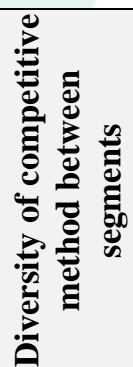 } & \multirow{2}{*}{ 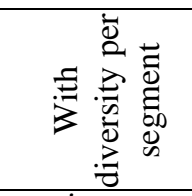 } & \multirow{4}{*}{ 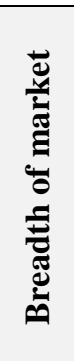 } & $\begin{array}{l}\text { Broad } \\
\text { scope }\end{array}$ & cluster 1 & cluster 2 & cluster 3 & \\
\hline & & & $\begin{array}{c}\text { Narrow } \\
\text { scope }\end{array}$ & cluster 4 & cluster 5 & cluster 6 & \\
\hline & 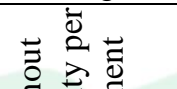 & & $\begin{array}{l}\text { Broad } \\
\text { scope }\end{array}$ & cluster 7 & cluster 8 & cluster 9 & $\begin{array}{c}\text { cluster } \\
10\end{array}$ \\
\hline & 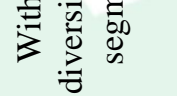 & & $\begin{array}{c}\text { Narrow } \\
\text { scope }\end{array}$ & cluster 11 & cluster 12 & cluster 13 & $\begin{array}{c}\text { cluster } \\
14\end{array}$ \\
\hline
\end{tabular}

Source: Chrisman et al. (1988)

\subsection{PERFORMANCE}

Firms choose a given strategic positioning as a means to achieve higher performance in a sustainable manner. Measuring performance, however, is something that requires adequate metrics, given the multidimensional nature of the concept to be measured. According to Chakravarthy (1986), measurement of performance must reflect the efficiency of a company's positioning in the industry and provide managers with some reference on the quality of their decisions, which can be made by means of compound indicators composing multiple measurements of the different dimensions involved.

According to Barney (2007), a company presents higher performance when it can actually create more economic value than its competitors. Despite the simplicity in this definition of performance, it proves to be less than practical since the concept of economic value, as defined by the difference in the value of benefits created for the customer and the production costs incurred, is difficult to measure. Barney classifies the most common performance measurements in four classes: profitability ratios, liquidity ratios, leverage ratios, and activity ratios.

Past financial data (ROA, ROE or other) may be useful for analysis and comparisons but it is a "picture" of a moment in time and says little about the "film" that has been playing (company's 
history and past progress) or will be playing (company's potential future performance). On the other hand, present-value measures, such as VPL and Tobin's Q (Barney, 2007), incorporate expected future performance prospects, measured at the present time, and may be appropriate to analyze long-term results especially when a company is taking actions that may be detrimental to short-term performance (such as R\&D expenditures to avoid technological obsolescence, or advertising expenditures to boost brand and reputation) as a way to build a stronger position and reap the benefits in the future.

\subsection{HYPOTHESES}

Firms are heterogeneous in terms of their histories, organizational structures and managers' profiles; and they may also face varied market challenges. It is therefore reasonable to assume that different firms in a given industry may employ different strategic types. This reasoning leads to the first hypothesis of this study:

$\boldsymbol{H}_{1}:$ There can be found distinct strategic types among MNCs in the oil industry

It has been argued that performance is influenced by strategy (Dess and Davis, 1984; Kim and Lim, 1988; Porter, 1985; Wright et al., 1991). Such assertion leads to the second hypothesis:

$\boldsymbol{H}_{2}$ : Distinct strategic types will be associated with distinct levels of performance in the oil industry

Some resources necessary for a firm to develop competitive advantage may have a long process of accumulation and may depend on consistent and continued efforts throughout a long period of time (Dierickx and Cool, 1989). Given this time-dependent pattern one can argue that, if a firm keeps changing its strategic positioning, it may not dedicate enough time for its resources to accumulate and lead to competitive advantage. This may be particularly true in the oil industry where complex new process and product technologies may have long maturation periods. The third hypothesis is advanced:

$\boldsymbol{H}_{3}$ : Stability of strategic positioning will be associated with higher levels of performance in the oil industry 
Strategic Positioning and Strategic Stability: Does it Matter to Performance?

\section{DATA AND METHODS}

\subsection{SAMPLE AND DATA COLLECTION PROCEDURES}

For the purposes of this study, the target population was defined as diversified oil companies (that is, acting in more than one product-market segment) operating on the exploration and production activity (whether or not operating in other productive activities of the oil chain or related industries). The first criterion is justified since Chrisman et al.'s (1988) typology has a dimension that refers to different corporate positions across segments, while the second criterion is due to the importance of exploration and production activities, since profits therefrom do correspond, not rarely, to $70 \%$ of the total profits of oil companies.

The sample was composed of public listed companies appearing the ranking by PIW (Petroleum Intelligence Weekly), the main business journal in the industry, whereto other companies were added because of their representativeness in the industry, in terms of both their market value and the volume of oil produced as of 2007 year end. The final sample was composed of 50 companies (Table 2).

Data about strategic variables and performance indicators were obtained from annual reports as well as from other communication and investor relations materials disclosed by the companies.

Data were collected for the years 2000 to 2007. This horizon was chosen as a function of the relative stability in oil prices during this period which was characterized by a high trend started in December 1998 that was maintained to the end of 2007, the last year with annual accounting statements published when this study was undertaken.

\subsection{MEASURES}

Table 2 - Sample of companies used in this study

\begin{tabular}{|c|c|c|c|c|}
\hline ExxonMobil(USA) & ENI (ITA) & Devon (USA) & Noble (USA) & XTO (USA) \\
\hline BP (UK) & Repsol-YPF (SPA) & Anadarko (USA) & Suncor (CAN) & EOG (USA) \\
\hline Shell (UK/NL) & Rosnet (RUS) & Apache (USA) & Murphy Oil (USA) & Denbury (USA) \\
\hline Petrochina (CHI) & Sinopec (CHI) & Occidental (USA) & MOL (HUN) & Plains (USA) \\
\hline
\end{tabular}


Jorge Ferreira da Silva, Walter Pereira Formosinho, Jorge Manoel Teixeira Carneiro \& Jorge Brantes Ferreira

\begin{tabular}{|c|c|c|c|c|}
\hline Chevron (USA) & Statoil (NOR) & CNR (CAN) & Nexen (CAN) & Pioneer (USA) \\
\hline Total (FRA) & Marathon (USA) & CNOOC (CHI) & Santos (AUST) & Forest (USA) \\
\hline Conoco (USA) & OMV (AUS) & Talisman (CAN) & Imperial (CAN) & Cabot (USA) \\
\hline Petrobras (BRA) & Encana (CAN) & Husky (CAN) & Newfield (USA) & Premier (USA) \\
\hline Gazprom (RUS) & Petrocanada (CAN) & Chesapeake (USA) & Pogo (USA) & Berry (USA) \\
\hline Lukoil (RUS) & Hess (USA) & Woodside (AUST) & Dominion (USA) & Questar (USA) \\
\hline
\end{tabular}

In this study, we chose Chrisman et al.'s (1988) typology to represent the alternatives for a company's strategic positioning. This choice is due to the apparently reasonable fact that oil companies may have achieved a position of balancing low costs and differentiation (according to theoretical arguments advanced by Hill, 1988). Furthermore, since several of these companies are active in different product segments and also in different countries, some may not be employing the same strategic positioning in all target markets - and Chrisman et al.'s (1988) typology allows for diversity of strategic positioning.

Broad scope strategies were considered to be those adopted by integrated oil companies operating in exploration and production (E\&P) activities as well as in refining and distribution. Those operating only in E\&P were considered as companies of narrow scope strategies.

Operationalization of the strategic types by Chrisman et al. (1988) is specific to each industry, since cost determinants as well as factors defining differentiation vary from industry to industry. The competitive methods adopted for this study were enlarged from the 18 methods of a study on the competitive strategies adopted by oil companies, conducted by Carneiro (1997), who derived those competitive methods from conversations with academic experts and Petrobras (the largest Brazilian oil company) executives. After additional conversations with academic and industry experts on which variables would be relevant to represent strategic positioning in the oil industry, 21 strategic variables were finally selected. The operationalization of these 21 variables is presented in Table 3. Association of each of those 21 competitive methods with low cost / low price vs. differentiation positions was done with the aid of experts. The classification of companies' strategies in terms of competitive weapon and presence (or not) of segment differentiation was 
Strategic Positioning and Strategic Stability: Does it Matter to Performance?

based on secondary data.

Table 3 - Strategic variables selected for this study and their operationalization

\begin{tabular}{|c|c|}
\hline STRATEGIC VARIABLE & OPERATIONALIZATION \\
\hline 1) Service Level & Sale Expenses / Sales Revenue \\
\hline 2) Sales Financing & Average Receivables Collection Period \\
\hline 3) Product Quality & Refining Conversion Intensity (\%) \\
\hline 4) Inventory Level & Number of Inventory Days \\
\hline 5) Control over Distribution Channels & Volume of Sales in Own Service Stations (\%) \\
\hline 6) Breadth of Product Line & Availability of Refining Capacity \\
\hline 7) Price Policy & Gross Margin \\
\hline 8) Availability of Raw Material & Volume of Reserves / Volume Produced \\
\hline 9) Innovation in Production Processes & R\&D Expenses / Sales Revenue \\
\hline 10) Cost Management & Total Operational Costs / Sales Revenue \\
\hline 11) Capital Structure & Ratio between net debt and capital employed \\
\hline 12) Operational Leverage & Fixed Costs / Total Costs \\
\hline 13) E\&P Costs (exploration \& production) & Costs of Acquisition + Exploration + Production per barrel \\
\hline 14) Exploratory Efficiency & Percentage of company success in drilling wells \\
\hline 15) Refining Capacity & $\begin{array}{l}\text { Production capacity in wholly-owned refineries }+ \text { proportional capacity } \\
\text { in partnerships }\end{array}$ \\
\hline 16) Use of Production Capacity & Volume processed / Refining capacity \\
\hline
\end{tabular}


Jorge Ferreira da Silva, Walter Pereira Formosinho, Jorge Manoel Teixeira Carneiro \& Jorge Brantes Ferreira

\begin{tabular}{|l|l|}
\hline 17) Employee Productivity & Operational profitability / Number of employees \\
\hline 18) Capital Intensity & Operational Capital / Total Revenues \\
\hline 19) Firm Size & Total value of assets \\
\hline 20) Differentiated Presence per Segment & Local margin - Margin in other regions \\
\hline 21) Degree of Internationalization & Local Sales Revenue / Total Sales Revenue \\
\hline
\end{tabular}

As for measures of performance, we chose Tobin's $Q$ as a measure of expected future performance and ROCE (return on capital employed) as a measure of past performance.

In order to create an indicator that could be used as a determinant for new investments, Tobin and Brainard (1968) developed a quotient that became known as Tobin's Q, a variable that was successful in different research applications in the area of economics and finance. Defined as the ratio between a company's market value (given by the value of its shares in the stock market) and the replacement value of its assets, Tobin's Q represents an investor assessment of expected future profits in comparison with the disbursements that would be necessary to build the company's physical assets from scratch. If $\mathrm{Q}>1$, it shows that the market expects the company to be able to generate cash flow that, discounted to present value, would be higher than the value to replace its assets.

ROCE (return on capital employed) is also a frequently used performance indicator and measures the overall efficiency of corporate management to generate operational profits with the available assets. While Tobin's $\mathrm{Q}$ is a measure that indicates expected future performances, ROCE measures past performance. Chung and Pruitt (1994) developed a simplified methodology for the calculation of an approximate Q, a simplification that turned the calculation of Tobin's Q into an easy operation by means of information that is commonly published in financial statements.

According to Copeland, Koller and Murrin (1995), the capital invested, which is the denominator in the ROCE formula, would correspond to the amount employed in company operations. It is composed of: operational working capital, fixed assets (net of accumulated depreciation) and other assets (already net of short term shareholders' equities that are exempted from interests). One of the limitations of ROCE is that its calculation is based on accounting values, 
which may undergo a series of distortions and do not, necessarily, correspond to market value (Hirschey and Wichern, 1984).

Considering that corporate business strategies are hardly ever implemented in a one year period, this study attempted to identify a company's strategic positioning in a given year by resorting to the average values (moving average) of the strategy variables in the last quarter.

\subsection{DATA TREATMENT PROCEDURES}

In the accounting years where data referring to a given company's market value of equity were found to be missing, estimated values were calculated on the basis of the first value informed in previous years, multiplied by a factor proportional to the rate of net profits obtained in both years. This method was particularly useful for estimating the market value of some companies privatized in the late 1990's whose shares, in the early years of the timeframe of this study, were not yet negotiated in the stock market.

In order to ensure homogeneity in the distribution of values for the variables under analysis, $\mathrm{Z}$ transforms of the variables were calculated, thus avoiding distortions resulting from different scales adopted in the measurements.

\subsection{ANALYTICAL TECHNIQUES}

Cluster analysis was used for the identification of strategic groups. According to Hair et al. (2005), cluster analysis may be used in an exploratory mode for deriving a taxonomy (empirical classification of cases) or in a confirmatory mode, starting from a previous theoretical classification that will be compared to empirical data. Here, the cluster analysis was run in a confirmatory mode for each year of the period under study, where the generic strategies of Chrisman et al.'s (1988) typology were used as the theoretical framework to form clusters (strategic groups) of companies. A corresponding cluster was associated to each type of strategy in Chrisman et al.'s (1988) classification scheme. The methodology used for cluster formation and analysis followed the following steps:

a) For each of the 14 strategic types by Chrisman et al. (1988), the typical values of each of the 21 strategic variables were defined (shown in Table 3), thus forming theoretical centroid references to represent a typical company in each of 14 theoretical clusters; these typical values were defined as the value expected, in theory, for each strategic variable (measured in 
Jorge Ferreira da Silva, Walter Pereira Formosinho, Jorge Manoel Teixeira Carneiro \& Jorge Brantes Ferreira

percentiles, at every $12.5 \%$ of the distribution of values for each variable) and are presented in Tables 4 and 5.

b) By using the Euclidean distance as a measure of similarity, each of the 50 companies studied here was associated with a particular cluster according to the proximity of the values of its strategic variables to the theoretical values used to define the clusters; in this procedure intra-cluster variations were minimized and inter-cluster variations were maximized.

c) After each company's allocation to its respective cluster, the group's reference (centroid) was recalculated. The procedure was repeated until all companies were associated with a cluster. As a confirmatory test of model stability, the differences between initial cluster centroids and final centroids were not statistically significant. In this procedure, Wilcoxon signed-rank (a nonparametric test) was used.

After the strategic groups for each year were formed, we identified the cluster in which a company was classified the greatest number of times - this cluster was named the company's “dominant cluster" (or “dominant strategic group”).

Once the clusters were formed, the average values of each group's performance variables were calculated and Kruskal-Wallis non-parametric H-Test (often viewed as the nonparametric equivalent of the parametric one-way analysis of variance (one-way ANOVA)) was run to check for differences in performance variables across strategic groups (clusters).

Nonparametric statistical methods were needed because, in some cases, data did not comply with the assumptions for the correct use of parametric methods, particularly as far as homocedasticity is concerned.

Based on the dominant strategic group criterion, the companies were associated with the clusters corresponding to their more frequent positioning and a new comparison of performance indicators was conducted, this time with the average performance values for the companies in the entire eight-year period. In case a company had employed two types of positioning for the same number of years (e.g., XTO), the most recent positioning was defined as the dominant.

Additionally, companies were classified in two groups according to the number of years they stuck to their dominant cluster: up to four years versus more than four years. New tests were run in order to verify possible association between stability of strategy positioning and performance. 
Strategic Positioning and Strategic Stability: Does it Matter to Performance?

Table 4 - Theoretical values (percentiles) of the strategic variables of each strategic type of Chrisman et al.'s (1988) typology with differentiation per segment

\begin{tabular}{|c|c|c|c|c|c|c|c|c|}
\hline & \multicolumn{4}{|c|}{ BROAD SCOPE } & \multicolumn{4}{|c|}{ NARROW SCOPE } \\
\hline $\begin{array}{l}\text { Competitive } \\
\text { Method }\end{array}$ & Low Cost* & Utility ** & Diferentiation & None & Low Cost * & Utility $* *$ & Diferentiation & None \\
\hline Service Level & 3 & 6 & 6 & & 2 & 5 & 5 & \\
\hline $\begin{array}{l}\text { Funding to } \\
\text { Sales }\end{array}$ & 3 & 6 & 6 & & 2 & 5 & 5 & \\
\hline $\begin{array}{l}\text { Product } \\
\text { Quality }\end{array}$ & 3 & 5 & 7 & & 1 & 3 & 5 & \\
\hline $\begin{array}{l}\text { Inventory } \\
\text { Level }\end{array}$ & 2 & 5 & 6 & & 2 & 5 & 6 & \\
\hline $\begin{array}{l}\text { Control of } \\
\text { Dist. Chan. }\end{array}$ & 3 & 5 & 7 & & 1 & 1 & 1 & \\
\hline $\begin{array}{l}\text { Breadth of } \\
\text { Product Line }\end{array}$ & 1 & 1 & 1 & & 0 & 0 & 0 & \\
\hline Price Policy & 1 & 3 & 5 & & 3 & 5 & 7 & \\
\hline $\begin{array}{l}\text { Availab. of } \\
\text { Raw Mats. }\end{array}$ & 7 & 5 & 4 & & 7 & 5 & 4 & \\
\hline $\begin{array}{l}\text { Innov. in } \\
\text { Prod. Procs. }\end{array}$ & 7 & 6 & 3 & & 6 & 5 & 2 & \\
\hline $\begin{array}{l}\text { Cost } \\
\text { Management }\end{array}$ & 3 & 6 & 7 & & 2 & 5 & 6 & \\
\hline $\begin{array}{l}\text { Capital } \\
\text { Structure }\end{array}$ & 6 & 6 & 6 & & 2 & 2 & 2 & \\
\hline $\begin{array}{l}\text { Operational } \\
\text { Leverage }\end{array}$ & 7 & 6 & 4 & & 6 & 5 & 3 & \\
\hline E\&P Costs & 2 & 2 & 2 & & 6 & 6 & 6 & \\
\hline $\begin{array}{l}\text { Exploratory } \\
\text { Efficiency }\end{array}$ & 7 & 5 & 3 & & 7 & 5 & 3 & \\
\hline $\begin{array}{l}\text { Refining } \\
\text { Capacity }\end{array}$ & 7 & 5 & 2 & & 1 & 1 & 1 & \\
\hline $\begin{array}{l}\text { Use of Ref. } \\
\text { Capacity }\end{array}$ & 7 & 5 & 2 & & 1 & 1 & 1 & \\
\hline
\end{tabular}


Jorge Ferreira da Silva, Walter Pereira Formosinho, Jorge Manoel Teixeira Carneiro \& Jorge Brantes Ferreira

\begin{tabular}{|l|c|c|c|c|c|c|c|c|}
\hline $\begin{array}{l}\text { Employee } \\
\text { Prod. }\end{array}$ & 6 & 5 & 3 & & 7 & 5 & 3 & \\
\hline $\begin{array}{l}\text { Capital } \\
\text { Intensity }\end{array}$ & 3 & 5 & 7 & & 2 & 4 & 6 & \\
\hline $\begin{array}{l}\text { Company } \\
\text { Size }\end{array}$ & 6 & 6 & 6 & & 2 & 2 & 2 & 6 \\
\hline $\begin{array}{l}\text { Dif. Presence } \\
\text { p/ Segment }\end{array}$ & 6 & 6 & 6 & & 6 & 6 & 6 & \\
\hline $\begin{array}{l}\text { Degree of } \\
\text { International. }\end{array}$ & 6 & 6 & 6 & & 6 & 6 & 6 \\
\hline
\end{tabular}

* low cost / low price

** balanced use of low cost / low price and differentiation

Basically, the difference between measuring performance variables in an year-to-year basis and doing so in accordance with the dominant cluster criterion (long term) is that, in the former, moving averages of three accounting years were used, whereas, in the latter, performance variables averages for the entire period were used. The effect of this latter approach is to further mitigate the year-to-year variations observed in company performance and positioning, and to provide the grounds for a more stable analysis of the relation between a company's strategic positioning to performance.

Table 5 - Theoretical values (percentiles) of the strategic variables in each strategic type of Chrisman et al.'s (1988) typology without differentiation per segment

\begin{tabular}{|l|c|c|c|c|c|c|c|c|}
\hline & \multicolumn{5}{c|}{ BROAD SCOPE } & \multicolumn{3}{c|}{ NARROW SCOPE } \\
\hline $\begin{array}{l}\text { Competitive } \\
\text { Method }\end{array}$ & Low Cost* & Utility ** & Diferentiation & None & Cost Price & Utility & Diferentiation & None \\
\hline Service Level & 3 & 6 & 6 & 4 & 2 & 5 & 5 & 4 \\
\hline $\begin{array}{l}\text { Funding to } \\
\text { Sales }\end{array}$ & 3 & 6 & 6 & 4 & 2 & 5 & 5 & 4 \\
\hline $\begin{array}{l}\text { Product } \\
\text { Quality }\end{array}$ & 3 & 5 & 7 & 4 & 1 & 3 & 5 & 4 \\
\hline $\begin{array}{l}\text { Inventory } \\
\text { Level }\end{array}$ & 2 & 5 & 6 & 4 & 2 & 5 & 6 & 4 \\
\hline
\end{tabular}


Strategic Positioning and Strategic Stability: Does it Matter to Performance?

\begin{tabular}{|c|c|c|c|c|c|c|c|c|}
\hline $\begin{array}{l}\text { Control of } \\
\text { Dist. Chan. }\end{array}$ & 3 & 5 & 7 & 4 & 1 & 1 & 1 & 1 \\
\hline $\begin{array}{l}\text { Breadth of } \\
\text { Product Line }\end{array}$ & 1 & 1 & 1 & 1 & 0 & 0 & 0 & 0 \\
\hline Price Policy & 1 & 3 & 4 & 4 & 3 & 5 & 7 & 4 \\
\hline $\begin{array}{l}\text { Availab. of } \\
\text { Raw Mats. }\end{array}$ & 7 & 5 & 4 & 4 & 7 & 5 & 4 & 4 \\
\hline $\begin{array}{l}\text { Innov. in } \\
\text { Prod. Procs. }\end{array}$ & 7 & 6 & 3 & 4 & 6 & 5 & 2 & 4 \\
\hline $\begin{array}{l}\text { Cost } \\
\text { Management }\end{array}$ & 3 & 6 & 7 & 4 & 2 & 5 & 6 & 4 \\
\hline $\begin{array}{l}\text { Capital } \\
\text { Structure }\end{array}$ & 6 & 6 & 6 & 6 & 2 & 2 & 2 & 2 \\
\hline $\begin{array}{l}\text { Operational } \\
\text { Leverage }\end{array}$ & 7 & 6 & 4 & 4 & 6 & 5 & 3 & 4 \\
\hline E\&P Costs & 2 & 2 & 2 & 2 & 6 & 6 & 6 & 6 \\
\hline $\begin{array}{l}\text { Exploratory } \\
\text { Efficiency }\end{array}$ & 7 & 5 & 3 & 4 & 7 & 5 & 3 & 4 \\
\hline $\begin{array}{l}\text { Refining } \\
\text { Capacity }\end{array}$ & 7 & 5 & 2 & 4 & 1 & 1 & 1 & 1 \\
\hline $\begin{array}{l}\text { Use of Ref. } \\
\text { Capacity }\end{array}$ & 7 & 5 & 2 & 4 & 1 & 1 & 1 & 1 \\
\hline $\begin{array}{l}\text { Employee } \\
\text { Prod. }\end{array}$ & 6 & 5 & 3 & 4 & 7 & 5 & 3 & 4 \\
\hline $\begin{array}{l}\text { Capital } \\
\text { Intensity }\end{array}$ & 3 & 5 & 7 & 4 & 2 & 4 & 6 & 4 \\
\hline $\begin{array}{l}\text { Company } \\
\text { Size }\end{array}$ & 6 & 6 & 6 & 6 & 2 & 2 & 2 & 2 \\
\hline $\begin{array}{l}\text { Dif. Presence } \\
\text { p/ Segment }\end{array}$ & 2 & 2 & 2 & 2 & 2 & 2 & 2 & 2 \\
\hline $\begin{array}{l}\text { Degree of } \\
\text { International. }\end{array}$ & 2 & 2 & 2 & 2 & 2 & 2 & 2 & 2 \\
\hline
\end{tabular}

* low cost / low price

** balanced use of low cost / low price and differentiation 
Jorge Ferreira da Silva, Walter Pereira Formosinho, Jorge Manoel Teixeira Carneiro \& Jorge

Brantes Ferreira

\section{FINDINGS}

Tables 6 and 7 present the average values of Tobin's Q and ROCE performance variables for the companies belonging to the clusters (strategic groups) that were formed, on an annual basis, in the period under study. Blank cells mean that no firms were associated with a given cluster in the respective year. At the bottom of the table, there are values of the chi-square statistics calculated for the Kruskal-Wallis H-Test each year. At the .10 significance level, no statistically significant differences in Tobin's Q values could be found across the clusters for any given year, except for year 2007 (significance level < .08). Consequently, there is no statistical evidence that strategic positioning would be associated with differences in expected future performance. On the other hand, a comparison of ROCE values paints a different picture. Except for the period 2004-2006, one can say that at least two clusters presented statistically significant (at .10 level or lower) differences in performance.

Table 6 - Average Tobin's Q for the strategic groups

\begin{tabular}{|c|c|c|c|c|c|c|c|c|}
\hline & 2000 & 2001 & 2002 & 2003 & 2004 & 2005 & 2006 & 2007 \\
\hline Cluster 1 & 2.3000 & - & - & - & - & - & - & 1.4962 \\
\hline Cluster 2 & 1.3201 & 1.4521 & 1.3393 & 1.2612 & 1.2312 & 1.4390 & 1.4609 & 1.8683 \\
\hline Cluster 3 & - & 1.1372 & 1.1178 & 1.1028 & 1.1869 & 1.2461 & 1.2699 & 1.4148 \\
\hline Cluster 4 & - & - & - & 1.3070 & 1.1943 & 1.2436 & 1.4789 & 1.4798 \\
\hline Cluster 5 & 1.3646 & 1.4232 & 1.3592 & 1.1432 & 1.3448 & 1.2021 & 1.3614 & 1.3301 \\
\hline Cluster 6 & 1.3770 & 1.1804 & 1.1652 & 1.2378 & 1.3149 & 2.2406 & 2.4146 & - \\
\hline Cluster 7 & - & - & - & - & - & - & - & - \\
\hline Cluster 8 & 1.6943 & 1.9658 & 1.6914 & 1.7196 & 1.5664 & 1.6021 & 1.7889 & 2.0107 \\
\hline Cluster 9 & - & 0.8307 & 0.8569 & 0.9928 & 1.0885 & 1.3176 & 1.1914 & 1.2101 \\
\hline
\end{tabular}


Strategic Positioning and Strategic Stability: Does it Matter to Performance?

\begin{tabular}{|c|c|c|c|c|c|c|c|c|}
\hline Cluster 10 & 1.0901 & 1.1150 & 1.1235 & 1.1644 & 1.2316 & 1.4599 & 1.8479 & 1.7684 \\
\hline Cluster 11 & 1.5413 & 1.5944 & 1.5029 & 1.3996 & - & & 1.1665 & 2.4158 \\
\hline Cluster 12 & 1.0750 & 0.7137 & 1.1477 & 1.5450 & 1.6676 & 1.5358 & 1.3851 & 1.8215 \\
\hline Cluster 13 & 1.3694 & - & - & - & - & - & - & - \\
\hline Cluster 14 & 1.5947 & 1.3296 & 1.3962 & 1.2738 & 1.5038 & 1.7374 & 1.7138 & 1.9000 \\
\hline Chi-Square & 10.2857 & 13.9591 & 12.1276 & 12.4532 & 11.3602 & 10.8866 & 15.4908 & 16.9658 \\
\hline Df & 9 & 9 & 9 & 10 & 9 & 9 & 10 & 10 \\
\hline Asymp. Sig. & 0.3279 & 0.1238 & 0.2062 & 0.2559 & 0.2518 & 0.2836 & 0.1152 & 0.0751 \\
\hline
\end{tabular}

Table 7 - Average ROCE for the strategic groups

\begin{tabular}{|c|c|c|c|c|c|c|c|c|}
\hline & 2000 & 2001 & 2002 & 2003 & 2004 & 2005 & 2006 & 2007 \\
\hline Cluster 1 & $13.69 \%$ & - & - & - & - & - & - & $23.76 \%$ \\
\hline Cluster 2 & $10.57 \%$ & $14.77 \%$ & $14.69 \%$ & $12.68 \%$ & $14.19 \%$ & $19.88 \%$ & $22.57 \%$ & $18.09 \%$ \\
\hline Cluster 3 & - & $11.32 \%$ & $11.69 \%$ & $9.79 \%$ & $11.24 \%$ & $14.58 \%$ & $16.99 \%$ & $18.08 \%$ \\
\hline Cluster 4 & - & - & - & $9.87 \%$ & $10.15 \%$ & $13.39 \%$ & $15.83 \%$ & $16.66 \%$ \\
\hline Cluster 5 & $7.84 \%$ & $10.77 \%$ & $11.51 \%$ & $9.48 \%$ & $12.05 \%$ & $14.56 \%$ & $17.41 \%$ & $14.79 \%$ \\
\hline Cluster 6 & $9.09 \%$ & $9.46 \%$ & $13.17 \%$ & $13.66 \%$ & $15.01 \%$ & $18.99 \%$ & $21.46 \%$ & - \\
\hline Cluster 9 & - & $6.64 \%$ & $8.20 \%$ & $9.89 \%$ & $12.72 \%$ & $15.98 \%$ & $16.10 \%$ & $16.68 \%$ \\
\hline
\end{tabular}


Jorge Ferreira da Silva, Walter Pereira Formosinho, Jorge Manoel Teixeira Carneiro \& Jorge Brantes Ferreira

\begin{tabular}{|c|c|c|c|c|c|c|c|c|}
\hline Cluster 10 & $9.65 \%$ & $13.25 \%$ & $14.06 \%$ & $15.05 \%$ & $16.01 \%$ & $18.80 \%$ & $23.15 \%$ & $22.78 \%$ \\
\hline Cluster 11 & $18.23 \%$ & $24.08 \%$ & $22.62 \%$ & $17.33 \%$ & - & - & $12.51 \%$ & $27.45 \%$ \\
\hline Cluster 12 & $2.92 \%$ & $0.99 \%$ & $6.41 \%$ & $12.28 \%$ & $13.74 \%$ & $14.76 \%$ & $16.47 \%$ & $15.97 \%$ \\
\hline Cluster 13 & $4.39 \%$ & - & - & - & - & - & - & - \\
\hline Cluster 14 & $6.24 \%$ & $16.70 \%$ & $15.22 \%$ & $12.40 \%$ & $13.77 \%$ & $18.42 \%$ & $16.87 \%$ & $16.88 \%$ \\
\hline Chi-Square & 16.4931 & 22.0347 & 18.8378 & 18.8016 & 9.5805 & 11.5139 & 14.2586 & 16.4267 \\
\hline Df & 9 & 9 & 9 & 10 & 9 & 9 & 10 & 10 \\
\hline Asymp. Sig. & 0.0573 & 0.0088 & 0.0266 & 0.0429 & 0.3855 & 0.2421 & 0.1615 & 0.0881 \\
\hline
\end{tabular}

So it seems that expectations about future performance (Tobin's Q) were not, later on, confirmed by actual results (ROCE), that is, while (ex-ante) expectations were about the same, actual (ex-post) results differed across strategy types. Such finding suggests that, although investors seem to believe that distinct strategy types may, per se, lead to similar performance results (a phenomenon of expected equifinality), actual results (measured ex-post) indicate otherwise.

It should be noted, however, that the specific companies that populated each of the clusters may not have been the same across each of the eight years of the study.

The strategic positioning of each company for each year is presented in Table 8. The dominant cluster column indicates the cluster where the company remained the longest as well as the duration of this permanence, measured in number of (not necessarily consecutive) years. An analysis of the data in Table 8 shows that some companies moved from a given cluster to another with frequent differences in their strategic positioning. Some companies, on the other hand, remained in the same cluster for the entire period, which is a sign of stability in their strategic positioning. 
Strategic Positioning and Strategic Stability: Does it Matter to Performance?

Table 8 - Movement of companies among strategic groups

\begin{tabular}{|c|c|c|c|c|c|c|c|c|c|c|}
\hline Companies & 2000 & 2001 & 2002 & 2003 & 2004 & 2005 & 2006 & 2007 & $\begin{array}{l}\text { Dominant } \\
\text { Cluster }\end{array}$ & $\begin{array}{l}\text { Nr. of } \\
\text { Years }\end{array}$ \\
\hline Anadarko & 14 & 5 & 5 & 5 & 4 & 4 & 14 & 5 & 5 & 4 \\
\hline Apache & 5 & 14 & 14 & 14 & 5 & 4 & 4 & 14 & 14 & 4 \\
\hline Berry & 11 & 11 & 11 & 11 & 12 & 14 & 14 & 12 & 11 & 4 \\
\hline BP & 2 & 2 & 2 & 2 & 2 & 2 & 2 & 1 & 2 & 7 \\
\hline Cabot & 5 & 5 & 12 & 12 & 14 & 14 & 14 & 12 & 12 & 3 \\
\hline Chesapeake & 13 & 14 & 14 & 14 & 4 & 12 & 11 & 14 & 14 & 4 \\
\hline Chevron & 2 & 2 & 2 & 3 & 3 & 2 & 2 & 1 & 2 & 5 \\
\hline $\mathrm{CNOOC}$ & 11 & 11 & 11 & 11 & 14 & 14 & 14 & 11 & 11 & 5 \\
\hline CNR & 11 & 14 & 14 & 14 & 14 & 12 & 12 & 4 & 14 & 4 \\
\hline Conoco & 10 & 3 & 8 & 3 & 3 & 2 & 2 & 1 & 3 & 3 \\
\hline Denbury & 13 & 14 & 14 & 14 & 14 & 12 & 14 & 14 & 14 & 6 \\
\hline Devon & 5 & 5 & 5 & 5 & 4 & 4 & 4 & 14 & 5 & 4 \\
\hline Dominion & 6 & 14 & 14 & 14 & 14 & 12 & 12 & 4 & 14 & 4 \\
\hline Encana & 10 & 10 & 10 & 10 & 10 & 10 & 10 & 10 & 10 & 8 \\
\hline ENI & 2 & 2 & 3 & 9 & 9 & 9 & 9 & 9 & 9 & 5 \\
\hline EOG & 6 & 5 & 14 & 12 & 14 & 14 & 4 & 14 & 14 & 4 \\
\hline Exxon & 1 & 2 & 2 & 2 & 2 & 2 & 2 & 1 & 2 & 6 \\
\hline Forest & 5 & 5 & 5 & 5 & 4 & 4 & 4 & 5 & 5 & 5 \\
\hline Gazprom & 2 & 2 & 2 & 2 & 2 & 8 & 8 & 2 & 2 & 6 \\
\hline Hess & 10 & 3 & 3 & 3 & 8 & 9 & 3 & 8 & 3 & 4 \\
\hline Husky & 10 & 10 & 10 & 10 & 10 & 10 & 10 & 10 & 10 & 8 \\
\hline Imperial & 8 & 8 & 8 & 8 & 8 & 9 & 10 & 8 & 8 & 6 \\
\hline Lukoil & 2 & 2 & 2 & 2 & 2 & 8 & 8 & 2 & 2 & 6 \\
\hline Marathon & 10 & 3 & 9 & 3 & 3 & 3 & 3 & 3 & 3 & 6 \\
\hline MOL & 8 & 9 & 9 & 9 & 9 & 9 & 9 & 9 & 9 & 7 \\
\hline Murphy & 10 & 3 & 3 & 3 & 3 & 3 & 3 & 3 & 3 & 7 \\
\hline Newfield & 5 & 5 & 5 & 4 & 4 & 14 & 14 & 12 & 5 & 3 \\
\hline Nexen & 5 & 5 & 5 & 5 & 5 & 5 & 5 & 5 & 5 & 8 \\
\hline Noble & 5 & 5 & 5 & 5 & 5 & 14 & 14 & 14 & 5 & 5 \\
\hline Occidental & 6 & 6 & 6 & 6 & 6 & 6 & 6 & 5 & 6 & 7 \\
\hline OMV & 10 & 3 & 9 & 3 & 9 & 9 & 9 & 9 & 9 & 5 \\
\hline Petrobras & 8 & 8 & 8 & 8 & 8 & 8 & 8 & 2 & 8 & 7 \\
\hline Petrocanada & 10 & 3 & 8 & 8 & 8 & 10 & 3 & 8 & 8 & 4 \\
\hline Petrochina & 8 & 8 & 8 & 8 & 9 & 8 & 8 & 2 & 8 & 6 \\
\hline Pioneer & 5 & 14 & 14 & 14 & 5 & 12 & 5 & 5 & 5 & 4 \\
\hline Plains & 11 & 11 & 11 & 11 & 12 & 12 & 14 & 12 & 11 & 4 \\
\hline Pogo & 5 & 5 & 5 & 4 & 4 & 14 & 14 & 5 & 5 & 4 \\
\hline Premier & 12 & 12 & 12 & 5 & 14 & 14 & 14 & 14 & 14 & 4 \\
\hline Questar & 6 & 5 & 14 & 12 & 12 & 12 & 14 & 12 & 12 & 4 \\
\hline Repsol & 10 & 3 & 3 & 3 & 3 & 3 & 3 & 3 & 3 & 7 \\
\hline Rosneft & 8 & 8 & 8 & 8 & 8 & 8 & 8 & 2 & 8 & 7 \\
\hline Santos & 6 & 14 & 14 & 14 & 14 & 12 & 4 & 14 & 14 & 5 \\
\hline Shell & 2 & 2 & 2 & 2 & 2 & 2 & 2 & 1 & 2 & 7 \\
\hline Sinopec & 8 & 9 & 9 & 9 & 9 & 9 & 9 & 2 & 9 & 6 \\
\hline Statoil & 10 & 10 & 10 & 10 & 10 & 10 & 10 & 10 & 10 & 8 \\
\hline Suncor & 8 & 8 & 8 & 8 & 8 & 8 & 8 & 8 & 8 & 8 \\
\hline Talisman & 5 & 5 & 14 & 14 & 5 & 12 & 4 & 4 & 5 & 3 \\
\hline Total & 2 & 2 & 2 & 2 & 2 & 2 & 2 & 3 & 2 & 7 \\
\hline Woodside & 6 & 14 & 14 & 14 & 14 & 6 & 6 & 14 & 14 & 5 \\
\hline XTO & 12 & 14 & 14 & 12 & 12 & 12 & 14 & 14 & 14 & 4 \\
\hline
\end{tabular}


Jorge Ferreira da Silva, Walter Pereira Formosinho, Jorge Manoel Teixeira Carneiro \& Jorge

Brantes Ferreira

Table 9 classifies companies according to their dominant cluster. Clusters 2, 5, and 8, which are comprised of companies that tried to obtain competitive advantage by means of balanced use of differentiation strategies and cost control, were more populated, as was cluster 14 (narrow-scope companies with no apparent differentiation or cost advantage).

Table 9 - Strategic groups defined according to dominant cluster

\begin{tabular}{|c|c|c|c|c|c|}
\hline \multicolumn{2}{|c|}{$2000-2007$} & COST/PRICE & UTILITY (COST + & DIFFERENTIATION & NONE \\
\hline \multirow{2}{*}{ 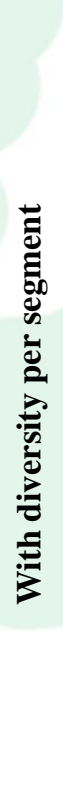 } & : & CLUSTER 1 & $\begin{array}{c}\text { CLUSTER 2 } \\
\text { BP } \\
\text { Chevron } \\
\text { Exxon } \\
\text { Gazprom } \\
\text { Lukoil } \\
\text { Shell } \\
\text { Total }\end{array}$ & $\begin{array}{c}\text { CLUSTER } 3 \\
\text { Marathon } \\
\text { Murphy } \\
\text { Repsol } \\
\text { Conoco } \\
\text { Hess }\end{array}$ & \\
\hline & Z & CLUSTER 4 & $\begin{array}{c}\text { CLUSTER } 5 \\
\text { Anadarko } \\
\text { Devon } \\
\text { Forest } \\
\text { Nexen } \\
\text { Noble } \\
\text { Pioneer } \\
\text { Pogo } \\
\text { Talisman } \\
\text { Newfield }\end{array}$ & $\begin{array}{c}\text { CLUSTER } 6 \\
\text { Occidental }\end{array}$ & \\
\hline \multirow{2}{*}{ 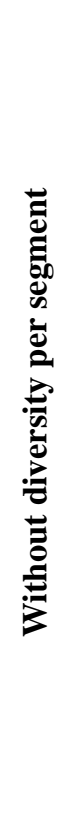 } & $\underset{\mathscr{E}}{T}$ & CLUSTER 7 & $\begin{array}{c}\text { CLUSTER } 8 \\
\text { Imperial } \\
\text { Petrobras } \\
\text { PetroCanada } \\
\text { PetroChina } \\
\text { Rosneft } \\
\text { Suncor }\end{array}$ & $\begin{array}{c}\text { CLUSTER } 9 \\
\text { ENI } \\
\text { MOL } \\
\text { OMV } \\
\text { Sinopec }\end{array}$ & $\begin{array}{c}\text { CLUSTER } 10 \\
\text { EnCana } \\
\text { Husky } \\
\text { Statoil }\end{array}$ \\
\hline & : & $\begin{array}{c}\text { CLUSTER } 11 \\
\text { Berry } \\
\text { CNOOC } \\
\text { Plains }\end{array}$ & $\begin{array}{c}\text { CLUSTER } 12 \\
\text { Questar } \\
\text { Cabot }\end{array}$ & CLUSTER 13 & $\begin{array}{c}\text { CLUSTER } 14 \\
\text { Apache } \\
\text { CNR } \\
\text { EOG } \\
\text { Chesapeake } \\
\text { Denbury } \\
\text { Dominion } \\
\text { Woodside } \\
\text { Premier } \\
\text { Santos } \\
\text { XTO }\end{array}$ \\
\hline
\end{tabular}


Strategic Positioning and Strategic Stability: Does it Matter to Performance?

As can be seen in Table 9, companies targeting a broad market scope do not often (or at all) employ low cost / low price strategies. As for narrow scope companies, there can be observed more variety of dominant strategic positioning.

This result is consistent with the study assumptions since, by our definition, broad scope companies are integrated companies operating in several steps of the chain of activities that add complementary value to the basic product - oil -, thereby differentiating their offer in relation to that of narrow scope companies.

Concerning the main strategic groups of broad scope and differentiation per segment, cluster 2 (companies that adopt utility as competitive method) is found to have been formed by companies operating globally and achieving highest revenues and net profits. These are differentiated offer companies that, by virtue of the scale of their operations, have also achieved good performance in the variables related to cost. Cluster 3 (of companies that adopt differentiation as a competitive method) was formed by companies that, despite operating globally, do not benefit from gains of scale like their peers from cluster 2. With regards to the main strategic groups of broad scope and without differentiation per segment, clusters 8 (of companies that adopt utility as competitive method), 9 (of companies that adopt differentiation as competitive method), and 10 (of companies that adopt no competitive method) are found to have been formed by companies, in average, of low degree of internationalization with a focus on their respective regional markets, which, by definition, represents lesser opportunities for differentiation per geographic segment than companies from clusters 2 and 3. In these groups, a greater number of state-controlled companies is found, which explains the regional emphasis of their operations.

Concerning the dominant strategic group of narrow scope and with differentiation per segment, cluster 5 (of companies that adopt utility as competitive method) is found to be formed by US and Canadian companies of global operations, considered large size participants in the upstream segment. These are companies that, in the time horizon of this study, have changed their positioning more frequently in relation to the others. Concerning the dominant strategic group of narrow scope and without differentiation per segment, cluster 14 (of companies without defined competitive method) is found to be formed mostly by US companies of regional operations considered middle size participants in the upstream segment. Like cluster 5 companies, these too have changed their positioning more frequently, having stayed, in average, about four years in their dominant cluster.

Table 10 presents the average values of performance indicators - in the entire period of 2000 through 2007 - for the companies grouped according to the dominant cluster criterion (including their performance in those years when they employed some strategic positioning other than their 
dominant positioning). The highest value of Tobin's $Q$ was observed in cluster 8, corresponding to broad scope companies without diversity per segment that have adopted a balanced differentiation strategy with cost control. This strategic group also presented the second best average ROCE.

Table 10 - Average value of performance indicators across dominant clusters (2000-2007)

\begin{tabular}{|l|c|c|c|c|c|c|c|c|c|c|}
\hline Dominant Cluster & 2 & 3 & 5 & 6 & 8 & 9 & 10 & 11 & 12 & 14 \\
\hline Tobin's Q & 1.39 & 1.16 & 1.32 & 1.32 & 1.89 & 1.06 & 1.31 & 1.71 & 1.59 & 1.53 \\
\hline ROCE & 0.16 & 0.12 & 0.12 & 0.14 & 0.17 & 0.12 & 0.16 & 0.21 & 0.12 & 0.14 \\
\hline
\end{tabular}

Kruskal-Wallis tests indicate that there are statistically significant differences (between at least two clusters) in average performance - considering the entire period 2000-2007 -, both in terms of Tobin's Q (.10 level) and of ROCE (.02 level) across clusters formed according to the dominant cluster criterion. For example, in the eight-year period, cluster 11 (focus cost strategy, i.e., narrow market scope, emphasis on low-cost / low price, and the same competitive weapons used in all segments) performed better while clusters 3, 5, 9 and 12 (comprised of companies with broadscope differentiation or with narrow-scope utility, irrespective of differentiated presence) performed worse in terms of past performance (ROCE). As for expected future performance (Tobin's Q), cluster 8 (mass market utility) performed better while cluster 9 (segmented utility focus) performed worse. This means that, taking a longer term (rather than annual) view of strategic positioning, there are statistically significant differences, both in past performance as well as in expected future performance, that is, some strategies seem to pay-off in the long term.

Comparing the results from this analysis of long term strategic positioning based on the dominant cluster criterion with the results obtained from the annual analysis, one can conjecture that shareholders' perceived value in relation to the strategies adopted in the different clusters can only be verified as the horizon of the analysis is extended, which represents an indication that perceived value seems to be related to long term positioning.

Table 11 shows the average values of performance variables according to the length of time each company remained in its respective dominant group. The sample was divided between companies that stayed up to four years and those that stayed more than four years in the same (dominant) cluster. 
Strategic Positioning and Strategic Stability: Does it Matter to Performance?

Table 11 - Effect of strategic stability in company performance

\begin{tabular}{|l|l|l|l|}
\hline \multirow{2}{*}{ Period of Permanence } & & Tobin's Q & ROCE \\
& & & \\
\hline \multirow{3}{*}{ Up to 4 years } & Mean & 1.3995 & 0.1353 \\
& $\mathrm{~N}$ & 20 & 20 \\
& Standard Dev. & 0.2535 & 0.0300 \\
\hline \multirow{3}{*}{ More than 4 years } & Mean & 1.4630 & 0.1509 \\
& $\mathrm{~N}$ & 30 & 30 \\
& Standard Dev. & 0.5499 & 0.0475 \\
\hline \multirow{3}{*}{ Total } & Mean & 1.4376 & 0.1446 \\
& $\mathrm{~N}$ & 50 & 50 \\
& Standard Dev. & 0.4526 & 0.0418 \\
\hline
\end{tabular}

According to the results presented, 30 out of the 50 companies analyzed herein stuck to a given strategic group for more than half of the eight years under analysis, whereas 20 companies changed their strategies more frequently and did not repeat the same strategy in more than four years. The effect of varying strategic positioning apparently bears some impact on company performance. Besides obtaining better ROCE, companies that kept their strategies for a longer period of time (i.e., maintained the same positioning for at least five of the eight years under analysis) obtained better results in terms of expected future performance (Tobin's Q). This result is an indication that investors seemed to have perceived greater value in the stability of strategic position. However, such performance differences should be viewed as indicative only, given that results of Kruskal-Wallis H-tests were not statistically significant $(p<.89$ for Tobin's Q and $p<.22$ for ROCE).

\section{CONCLUSIONS}

The main objective of this research was to investigate whether multinationals in the oil industry have adopted distinct strategic positioning and whether there seems to be some association between strategic positioning and firm performance. A cluster analysis of $50 \mathrm{MNCs}$, whereby the centroids were theoretically defined after Chrisman, et al.'s (1998) typology of generic strategies (operationalized by the relative emphasis on 21 competitive methods), identified 10 distinct strategic types employed by oil MNCs, thus corroborating $\mathrm{H}_{1}$.

Although no statistically significant differences could be found in the expectations of future performance (measured as Tobin's Q) on an annual basis, there were, however, statistically 
significant differences in the actual past performance (measured as ROCE - return on capital employed) between at least two strategic types in five out of the eight years $(2000-2007)$ of the study. Further analysis indicated that, on the long run, some strategic types did present higher expected future performance and some (not necessarily the same) achieved higher past performance (both performance results averaged over the eight-year period). So, results provide partial support for $\mathrm{H}_{2}$.

The relatively extensive window of time employed (eight years) has entailed the possibility of analyzing company performance on both an annual basis and a long term perspective. In fact, stability in strategic positioning (i.e., sticking to a given strategy for a longer period of time) also was associated (although not statistically significant) with better performance (both past and expected future), corroborating $\mathrm{H}_{3}$. All in all, findings indicate that strategy seems to bear an effect on performance in the oil industry.

Is should be noted that Chrisman et al. (1988) did not suggest that a given strategic positioning (among the 14 in their typology) would necessarily lead to better (or worse thereof) performance than the others. In fact their typology is descriptive rather than normative. That is why it is interesting to investigate whether there might be some association between strategic positioning and performance and whether such associations might be contingent on particular circumstances of the industry, the temporal frame or other environment or firm variables.

From an academic perspective, this study indicates that Chrisman et al.'s (1988) typology seems to be adequate for the classification of MNC's strategies in the oil industry both in terms of descriptive and explanatory perspectives, since competitive strategies could be mapped and consistent groups were formed and, furthermore, associations between strategic types and performance were found. The analyses developed in this research have brought forth not only the possibility of a company being differentiated and, and at the same time, presenting low operational cost, but also pointed at a group of companies that used this competitive method as the one where shareholders' perceived value was greater.

The findings can also be helpful from a practical standpoint. If further studies indicate that a given strategic type seems to lead to better performance in the oil industry, managers can direct efforts in order to develop such strategic positioning. However, the ability of a given positioning to provide better results may be contingent on the characteristics of the companies themselves and on environmental circumstances - a point that was not investigated in the present study - and on consistently pursuing the strategy instead of moving from a given strategic type to another.

This study has some limitations. First, it should be acknowledged that findings might not have 
been the same had different (conceptually acceptable) definitions of the theoretical centroids of the strategy types been employed.

Second, the very design of the research does not immediately support inferences of causeeffect relationships. In fact, the association between strategic positioning and performance uncovered in this study is merely indicative and should be further investigated with other multivariate techniques.

One should be careful before extending these findings to other industries. The oil industry has many idiosyncrasies (commodity-like, scale-economies, political interference, volatility in prices, tacit collusion among large players, regulation, among others particular features), so that the very strategic types found in this study might not be found in other industries; moreover, the types of strategy that would lead to better (worse) performance might differ in other industries.

Future studies could apply the methodology used in this study to a horizon that will include 2008 and 2009 accounts in order to detect occasional changes to strategic groupings that may have occurred, given oil price variations.

Another interesting line of investigation would be a modification of the concept of segmentation. As adopted in this study, segmentation followed the geographic criterion. Alternatively, a criterion of segmentation per business units could be used, where diversity per segment would be measured as the company's positioning in its different areas of operations. Still another suggestion could be to test the use of other performance variables to measure company performance and also the use of a multi-dimension approach to performance measurement. 


\section{REFERENCES}

Barney, J. B. (2007) Gaining and Sustaining Competitive Advance. New Jersey: Prentice Hall.

Carneiro, J. (1997). Alteração nas Estratégias Competitivas Decorrentes de Desregulamentação e de Privatizações na Indústria do Petróleo: Um Estudo de Casos. (Change of Competitive Strategies as a Response to Deregulation and Privatization in the Oil Industry: A Multiple-Case Study.) Master's Dissertation presented at the Pontifical Catholic University of Rio de Janeiro.)

Chakravarthy, B. S. (1986) Measuring Strategic Performance. Strategic Management Journal, 7(5), 437-458.

Chung, K; Pruitt, S. (1994) A Simple Approximation of Tobin's Q. Financial Management, 23(3), 70-74.

Chrisman, J.; Hofer, C. W. and Boulton, W. (1988) Toward a System for Classifying Business Strategies. Academy of Management Review, 13(3), 413-428.

Copeland, T., Koller, T. and Murrin, J. (1995).Valuation: Measuring and Managing the Value of Companies. $2^{\text {nd }}$ ed., New York: John Wiley \& Son, Inc.

Dess, G.; Davis, P. (1984) Porter's (1980) Generic Strategies as Determinants of Strategic Group Membership and Organizational Performance. Academy of Management Journal, 27(3), 467488.

Dierickx, I. and Cool, K. (1989). Asset Stock Accumulation and Sustainability of Competitive Advantage. Management Science, 35(12), 1504-1511.

Hair, J. F., Black, W. C., Babin, B. J., Anderson, R. E. and Tatham, R. L. (2005) Multivariate Data Analysis. New Jersey: Prentice Hall.

Hambrick, D. (1983) An Empirical Typology of Mature Industrial-Product Environments. Academy of Management Journal, 26, 213-230.

Hill, C. (1988) Differentiation versus Low Cost or Differentiation and Low Cost: A Contingency Framework. Academy of Management Review, 13(3), 401-412.

Hirschey, M. and Wichern, D. (1984) Accounting and Market-Value Measures of Profitability: Consistency, Determinants and Uses. Journal of Business and Economic Statistics, 2(44), 375-383. 
Strategic Positioning and Strategic Stability: Does it Matter to Performance?

Kim, L and Lim, Y. (1988). Environment, Generic Strategies and Performance in a Rapidly Changing Country: A Taxonomic Approach, Academy of Management Journal, 31, 802-827.

McGahan, A. and Porter, M. (2002) What Do We Know About Variance in Accounting Profitability? Management Science, 48, 834-851.

and (2002) How Much Does Industry Matter, Really?. Strategic Management Journal, 18, 15-30.

Miller, A. and Dess, G. G. (1993) Assessing Porter's (1980) Model in Terms of Its Generability, Accuracy and Simplicity, Journal of Management Studies, 30(4), 553-585.

Miller, D. (1981) Toward a New Contingency Approach: The Search for Organizational Gestalts. Journal of Management Studies, 18(1), 1-26.

Mintzberg, H. (1988) Generic Strategies: Toward a Comprehensive Framework. In Shrivastava, Paul (ed.), Advances in Strategic Management, Greenwich, CT: JAI Press, 5, 1-67.

Namiki, N. (1994) A Taxonomic Analysis of Export Marketing Strategy: An Exploratory Study of U.S. Exporters of Electronic Products. Journal of Global Marketing, 8(1), 27-50.

Porter, M. E. (1985) Competitive Advantage: Creating and Sustaining Competitive Performance, New York: The Free Press.

Roquebert, J., Phillips, R. and Wesrfall, P. (1996) Markets vs. Management: What Drives Profitability? Strategic Management Journal, 17, 653-664.

Ross, S., Westerfield, R. and Jordan, B. (2000) Fundamentals of Corporate Finance. McGraw-Hill.

Rumelt, R. (1991) How Much Does Industry Matter?. Strategic Management Journal, 12, 167-85.

Tobin, J. and Brainard, W. (1968) Pitfalls in Financial Model Building. American Economic Review, 58(2), 99-122.

Venkatraman, N. and Prescott, J. (1990) Environment-Strategy Coalignment: An Empirical Test of Its Performance Implications. Strategic Management Journal, 11, 1-23.

Wright, P. (1987) A Refinement of Porter's Strategies. Strategic Management Journal, 8, 93-101.

Wright, P., Kroll, M., Chan, P. and Hamel, K. (1991) Strategic Profiles and Performance: An Empirical Test of Select Key Propositions. Journal of the Academy of Marketing Science, 19(3), 245-254. 
Jorge Ferreira da Silva, Walter Pereira Formosinho, Jorge Manoel Teixeira Carneiro \& Jorge

Brantes Ferreira

Recebido: 22/06/2013

Aprovado: 04/08/2013 